\title{
Efficacy of Cry1Ac toxin from Bacillus thuringiensis against the beet armyworm, Spodoptera exigua (Hübner) (Lepidoptera: Noctuidae)
}

\author{
Muhammad Ibrahim Shahid', Muhammad Arshad ${ }^{1 *}$, Mansoor ul Hasan $^{1}$ and Muhammad Aslam Khan²
}

\begin{abstract}
Transgenic Bacillus thuringiensis (Bt) cotton is engineered to express delta endotoxin (Cry toxin) proteins in lepidopteran midgut when ingested by lepidopteran larvae such as the beet armyworm, Spodoptera exigua (Hübner). The efficacy of Bt technology depends on stage, age, and susceptibility of the tested population to Cry proteins. The baseline susceptibility bioassay test for first, second, and third larval instars of S. exigua, collected from Faisalabad, Multan, and Bahawalpur, compared with susceptible laboratory population was carried out in 2015 and 2016. The $L C_{50}$ ranged from 0.45 to $2.52 \mu \mathrm{g} \mathrm{ml}^{-1}, 1.08$ to $5.74 \mathrm{\mu g} \mathrm{ml}^{-1}$, and 2.01 to $7.85 \mathrm{\mu g} \mathrm{ml}^{-1}$ for first, second, and third larval instars, respectively. The Bahawalpur population was highly resistant and showed 5.63, 5.30, and 3.89 variations than the susceptible population, followed by Multan 3.01, 3.71, 3.10, and Faisalabad 1.93, 2.41, 2.31 population for first, second, and third larval instars, respectively. The molt inhibitory concentration $\left(\mathrm{MIC}_{50}\right)$ ranged from 0.04 to $0.56 \mathrm{\mu g} \mathrm{ml}^{-1}, 0.08$ to $0.99 \mathrm{\mu g} \mathrm{ml}^{-1}$, and 0.10 to $1.42 \mathrm{\mu g} \mathrm{ml}^{-1}$ for the three instars, respectively. The trend in lethal concentration and its respective resistance level was higher in 2016 than in 2015.
\end{abstract}

Keywords: Transgenic Bt cotton, Cry toxin, Spodoptera exigua, Bioassay

\section{Background}

The beet armyworm, Spodoptera exigua (Hübner) (Lepidoptera: Noctuidae), is a polyphagous pest of various field crops including vegetables, cotton, and ornamentals. S. exigua attacks the cotton plants throughout the whole growing season causing yield losses (Osoria et al. 2008). The widespread adoption of $B t$ cotton has led to several non-target insect pests such as mirids (Lu et al. 2010) aphids (Zhang et al. 2012), and armyworms including the beet armyworm that becomes one of the major pests in $B t$ cotton fields (Arshad and Suhail, 2011). However, Bt cotton expressing only CrylAc proteins are unable to provide effective control against Spodoptera spp. (Ponsard et al. 2002; Hofs et al. 2004; Selvi et al. 2012). Farmers have to spray insecticide even in $B t$ crops for effective

\footnotetext{
* Correspondence: arshaduaf@gmail.com

${ }^{1}$ Department of Entomology, University of Agriculture Faisalabad, Faisalabad 38040, Pakistan

Full list of author information is available at the end of the article
}

control of S. exigua (Smith, 1997). The susceptibility of tested insects to Cry toxins and changes in the baseline, due to the selection pressure of Cry1Ac crops, can be monitored through regular bioassays of the field populations (Heckel, 1993).

Insecticidal protein such as Bt protein is one of the integral parts of good management practices (GMP). It has been regarded as intra-complementary approach for natural enemies establishment when chemical control has been based on selective insecticides. Bt Cry proteins solubilize the midgut receptors and insert toxin to apical membrane and epithelium. This action causes death of treated larvae. These management tactics enable the insect to establish its colony. But the level of the toxin may vary in consistency due to adulteration and impurity. This action of breeders made the lepidopteran insects possible to infest the Bt plants and to establish their population. Under these circumstances, the beet armyworm gained substantial importance by regularly damaging the Bt plants. 
A susceptibility test in view of baseline bioassay has been addressed in few parts of the world including Indian and Chinese Spodoptera population to Cry1Ac. The scientists studied monitoring of resistance in Pakistan but still Cry1Ac susceptibility on S. exigua is lacking. Therefore, the present study was carried out to evaluate the efficacy of Cry1Ac toxin from $B t$ against the beet armyworm, $S$. exigua, under laboratory conditions.

\section{Material and methods}

\section{Larval collection}

The larvae of $S$. exigua were collected from Faisalabad, Bahawalpur, and Multan to develop laboratory colonies in 2015 and 2016. The field-collected populations were assigned as Faisalabad (FSD), Bahawalpur (BWP), and Multan (MLT). The collected larvae were placed in glass vials provided with semi-synthetic diet and transported to the Insect Biodiversity and Biosystematics Laboratory, Department of Entomology, University of Agriculture Faisalabad. The susceptible laboratory population was obtained from the Nuclear Institute of Agriculture and Biotechnology (NIAB), Faisalabad.

\section{Artificial diet}

The field and susceptible populations were reared on artificial diet as reported by (Shorey and Hale, 1965; Hamed and Nadeem, 2008)

\section{Rearing procedure}

Larvae were reared at $25 \pm 5{ }^{\circ} \mathrm{C}$ and $75 \pm 5 \% \mathrm{RH}$ under $16 \mathrm{~h} / 8 \mathrm{~h} \mathrm{~L} / \mathrm{D}$ cycle on the artificial diet and allowed to pupate. Pupae were collected and placed in a Petri plate. The pupae were disinfected in a $0.2 \%$ sodium hypochlorite solution. Petri plates containing pupae were placed in plastic containers until adult emergence. Adults were kept in open plastic containers covered with white netting. Adult diet $(10 \%$ $(\mathrm{v} / \mathrm{v})$ honey solution) was provided by soaking the cotton wool pad in the honey solution and placed on the top of the netting cage. Every $48 \mathrm{~h}$, egg-laden netting was replaced, and this process was repeated until egg production decreased or no further eggs were required. The netting was cut into small squares, and the netting containing eggs was surface sterilized in $0.05 \%$ sodium hypochlorite solution before being placed in a $250-\mathrm{ml}$ round plastic cups sealed with plastic lids. The cups were placed in a controlled environment room until eggs hatching. From the first (F1) generation neonates, three larval instars $\left(\mathrm{L}_{1}\right),\left(\mathrm{L}_{2}\right)$, and $\left(\mathrm{L}_{3}\right)$ were used for bioassays.

\section{Bacillus thuringiensis toxin}

Bt Cry1Ac toxin was obtained from Genralpest Biotech Research Co. Ltd, Beijing, China and was stored at $-20{ }^{\circ} \mathrm{C}$. It had been expressed as crystalline inclusions in Escherichia coli, with the protoxins purified by sonication and successive washes with $0.5 \mathrm{M} \mathrm{NaCl}$ and water as described by Sayyed et al. (2008). The toxin was freshly prepared in distilled water for diet incorporation.

\section{Diet incorporates bioassays}

Diet incorporation method was used for conducting bioassay, which is similar to the methods established for the baseline susceptibility of Helicoverpa armigera to $B$. thuringiensis toxins (Wei et al. 2017). Seven concentrations $\left(0.25,0.50,1,2,4,8,16 \mu \mathrm{g} \mathrm{ml}^{-1}\right)$ of Cry1Ac and a control were prepared. The artificial diet preparation was similar to that as described earlier except for the exclusion of ampicillin and a 10\% reduction in a distilled water. Approximately $5 \mathrm{ml}$ of the diet containing a toxin concentration was placed into a small aerated cup. Four replications were used for each bioassay. All bioassays were carried out under controlled environment in a growth chamber at $25 \pm 2{ }^{\circ} \mathrm{C}, 65 \pm 10 \%$ (RH) with a $16: 8$ (light/dark) cycle.

\section{Data statistical analysis}

The molt inhibitory and mortality rates were recorded after 7 days of bioassay. Molt inhibition was recorded when the larvae were unable to molt to the next larval instar. These counts were considered dead larvae. The mortality rate was recorded when larvae failed to respond with a gentle touch of a fine brush and considered as dead. The molt inhibition and mortality data were corrected from control mortality by Abbott formula (Abbott 1925), where needed. Probit analyses were done with PoloPlus (LeOra Software, 2003). The $\mathrm{LC}_{50}$ and $\mathrm{MIC}_{50}$ values, with their related fiducial limits at $95 \%$, were assessed. The resistance ratios were determined by dividing $\mathrm{LC}_{50} / \mathrm{MIC}_{50}$ of field with susceptible laboratory population. $\mathrm{LC}_{50}$ and $\mathrm{MIC}_{50}$ values were considered significantly different when they did not overlap each other with their respective 95\% fiducial limits.

\section{Results and discussion}

\section{Lethality of Cry1Ac toxin against S. exigua in 2015}

$\mathrm{L}_{1}, \mathrm{~L}_{2}$, and $\mathrm{L}_{3}$ larvae of $S$. exigua collected from FSD, MLT, and BWP exhibited variable responses to different levels of Cry1Ac toxin in terms of obtained lethal concentration values $\left(\mathrm{LC}_{50}\right)$. The BWP population showed a maximum $\mathrm{LC}_{50}$ value for all instars, followed by MLT while the lowest value was estimated for FSD population. The susceptible population showed the least $\mathrm{LC}_{50}$ (Table 1). The lethal concentrations ranged from 0.45 to $2.52 \mu \mathrm{g} \mathrm{ml}^{-1}$ for $\mathrm{L}_{1}, 1.08$ to $5.74 \mu \mathrm{g} \mathrm{ml} \mathrm{m}^{-1}$ for $\mathrm{L}_{2}$ and 2.01 to $7.85 \mu \mathrm{g} \mathrm{ml}{ }^{-1}$ for $\mathrm{L}_{3}$ (Table 1). The field populations showed a variation in susceptibility 
Table 1 Lethal concentration of susceptible and field population of Spodoptera exigua to Cry1Ac toxin during 2015

\begin{tabular}{|c|c|c|c|c|c|c|c|}
\hline Larval instars & POP & $\mathrm{LC}_{50}$ & Fiducial limit & Equation & $x^{2}$ & $\mathrm{RR}$ & $P$ value $(\mathrm{df}=5)$ \\
\hline \multirow[t]{4}{*}{$\overline{L_{1}}$} & SS & $0.45 \pm 0.03$ & $0.02-0.99^{a}$ & $0.17+1.09$ & 9.82 & 1 & 0.08 \\
\hline & FSD & $0.86 \pm 0.06$ & $0.23-1.95^{\mathrm{ab}}$ & $0.16 X+0.67$ & 9.50 & 1.93 & 0.09 \\
\hline & MLT & $1.35 \pm 0.08$ & $0.31-3.09^{\mathrm{abc}}$ & $0.15 X-0.21$ & 14.09 & 3.01 & 0.01 \\
\hline & BWP & $2.52 \pm 0.09$ & $1.01-4.87^{\mathrm{bcd}}$ & $0.14 X+0.44$ & 11.81 & 5.63 & 0.04 \\
\hline \multirow[t]{4}{*}{$\mathrm{L}_{2}$} & SS & $1.08 \pm 0.06$ & $0.46-2.75^{\mathrm{a}}$ & $0.17+0.94$ & 6.19 & 1 & 0.29 \\
\hline & FSD & $2.62 \pm 0.51$ & $1.21-4.51^{\mathrm{ab}}$ & $0.16 X+0.57$ & 7.73 & 2.41 & 0.17 \\
\hline & MLT & $4.02 \pm 0.89$ & $3.04-6.81^{b c}$ & $0.13 X+0.30$ & 6.83 & 3.71 & 0.23 \\
\hline & BWP & $5.74 \pm 1.13$ & $3.76-7.14^{\mathrm{bcd}}$ & $0.14 X-0.09$ & 7.60 & 5.30 & 0.02 \\
\hline \multirow[t]{4}{*}{$\mathrm{L}_{3}$} & SS & $2.01 \pm 0.95$ & $1.00-4.02^{\mathrm{a}}$ & $0.13+0.609$ & 1.21 & 1 & 0.94 \\
\hline & FSD & $4.65 \pm 1.02$ & $2.02-8.11^{\mathrm{ab}}$ & $0.14 X+0.39$ & 5.49 & 2.31 & 0.36 \\
\hline & MLT & $6.24 \pm 1.38$ & $2.72-9.48^{\mathrm{abc}}$ & $0.14 X+0.20$ & 9.57 & 3.10 & 0.09 \\
\hline & BWP & $7.85 \pm 3.28$ & $4.45-10.76^{\mathrm{bcd}}$ & $0.16 X-0.02$ & 8.78 & 3.89 & 0.12 \\
\hline
\end{tabular}

Different letters in the same column indicate significant differences due to non-overlapping basis of $95 \% \mathrm{Cl}$

levels across all populations up to a 5.63-fold for $\mathrm{L}_{1}$, 5.30-fold for $\mathrm{L}_{2}$ and 3.89-fold for $\mathrm{L}_{3}$. The molt inhibitory concentration ranged from 0.04 to $0.56 \mu \mathrm{g} \mathrm{ml}^{-1}$, 0.08 to $0.99 \mu \mathrm{g} \mathrm{ml}^{-1}$ and 0.10 to $1.42 \mu \mathrm{g} \mathrm{ml}^{-1}$ for $\mathrm{L}_{1}, \mathrm{~L}_{2}$, and $\mathrm{L}_{3}$. The data also recorded 12.51 -fold $\left(\mathrm{L}_{1}\right), 12.92$ fold $\left(\mathrm{L}_{2}\right)$, and 13.66-fold $\left(\mathrm{L}_{3}\right)$ variations in susceptibility levels among all the tested populations (Table 2).

\section{Lethality of Cry1 Ac toxin against S. exigua in 2016}

The collected S. exigua population in 2016 showed a considerable variability in $\mathrm{LC}_{50}$ basis of all bio-assayed instars (Table 3). The $\mathrm{LC}_{50}$ values ranged from 0.45 to $2.83 \mu \mathrm{g} \mathrm{ml}^{-1}, 1.10$ to $5.91 \mu \mathrm{g} \mathrm{ml}^{-1}$, and 2.01 to $7.85 \mu \mathrm{g}$ $\mathrm{ml}^{-1}$ for $\mathrm{L}_{1}, \mathrm{~L}_{2}$, and $\mathrm{L}_{3}$, respectively. $\mathrm{L}_{1}$ showed 6.25fold variations, followed by $\mathrm{L}_{2}$ (5.35-fold) and $\mathrm{L}_{3}$ (3.89fold) in susceptibility across all populations. The molt inhibitory concentrations ranged from 0.05 to $0.63 \mu \mathrm{g}$ $\mathrm{ml}^{-1}, 0.08$ to $1.23 \mu \mathrm{g} \mathrm{ml}^{-1}$, and 0.11 to $1.71 \mu \mathrm{g} \mathrm{ml}^{-1}$, for $\mathrm{L}_{1}, \mathrm{~L}_{2}$, and $\mathrm{L}_{3}$, respectively. The data also identified 13.43-fold $\left(\mathrm{L}_{1}\right)$, 15.63-fold $\left(\mathrm{L}_{2}\right)$, and 15.44-fold $\left(\mathrm{L}_{3}\right)$ variations in susceptibility levels among all the tested populations (Table 4). The results also clearly indicated that BWP population was highly resistant to Cry1Ac toxin than MLT and FSD populations. The level of resistance increased with time as depicted through 2015 and 2016 analysis.

The toxicological studies (Kashyap and Amla, 2007), by applying the $B t$ against American and armyworms, resulted in $\mathrm{LC}_{50}$ for $S$. litura by $0.11 \mu \mathrm{g}$. Bernardi et al. (2014) determined the baseline susceptibility test against S. frugiperda and Diatraea saccharalis. The $\mathrm{LC}_{50}$ mortality was 61.18 and $367.86 \mathrm{ng}$ Vip3Aa20 $\mathrm{cm}^{-2}$ for the 6 populations of D. saccharalis, and between 92.38 to $611.65 \mathrm{ng}$ Vip3Aa20 $\mathrm{cm}^{-2}$ for 16

Table 2 Molt inhibitory concentration of susceptible and field population of Spodoptera exigua to Cry1Ac toxin during 2015

\begin{tabular}{|c|c|c|c|c|c|c|c|}
\hline Larval instars & POP & $\mathrm{MIC}_{50}$ & Fiducial limit & Equation & $x^{2}$ & RR & $P$ value $(\mathrm{df}=5)$ \\
\hline \multirow[t]{4}{*}{$\overline{L_{1}}$} & SS & $0.04 \pm 0.00$ & $0.01-0.03^{\mathrm{a}}$ & $-0.20 X-2.60$ & 1.99 & 1 & 0.85 \\
\hline & FSD & $0.09 \pm 0.00$ & $0.01-0.38^{\mathrm{ab}}$ & $-0.14 X-1.47$ & 0.62 & 2.09 & 0.99 \\
\hline & MLT & $0.24 \pm 0.03$ & $0.07-0.62^{b c}$ & $-0.14 X-1.27$ & 0.18 & 5.36 & 0.99 \\
\hline & BWP & $0.56 \pm 0.04$ & $0.10-1.10^{c d}$ & $-0.15 X-1.06$ & 1.54 & 12.51 & 0.91 \\
\hline \multirow[t]{4}{*}{$L_{2}$} & SS & $0.08 \pm 0.01$ & $0.03-0.14^{a}$ & $-0.12 X-1.89$ & 0.07 & 1 & 1.00 \\
\hline & FSD & $0.22 \pm 0.04$ & $0.07-0.80^{\mathrm{ab}}$ & $-0.12 X-1.08$ & 1.49 & 2.83 & 0.91 \\
\hline & MLT & $0.62 \pm 0.51$ & $0.09-1.41^{b c}$ & $-0.13 X-0.88$ & 1.10 & 8.06 & 0.95 \\
\hline & BWP & $0.99 \pm 0.12$ & $0.33-2.01^{\mathrm{cd}}$ & $-0.11 X-0.60$ & 0.89 & 12.92 & 0.97 \\
\hline \multirow[t]{4}{*}{$\mathrm{L}_{3}$} & SS & $0.10 \pm 0.07$ & $0.05-0.31^{\mathrm{a}}$ & $-0.13 X-1.72$ & 0.38 & 1 & 0.99 \\
\hline & FSD & $0.49 \pm 0.10$ & $0.09-0.81^{\mathrm{ab}}$ & $-0.12 X-0.94$ & 1.49 & 4.76 & 0.91 \\
\hline & MLT & $0.80 \pm 0.21$ & $0.21-1.43^{b c}$ & $-0.13 X-0.73$ & 0.69 & 7.72 & 0.98 \\
\hline & BWP & $1.42 \pm 0.41$ & $0.80-3.05^{\mathrm{cd}}$ & $-0.12 X-0.46$ & 0.21 & 13.66 & 0.99 \\
\hline
\end{tabular}


Table 3 Lethal concentration of susceptible and field population of Spodoptera exigua to Cry1Ac toxin during 2016

\begin{tabular}{|c|c|c|c|c|c|c|c|}
\hline$\underline{\text { Larval instars }}$ & POP & $\mathrm{LC}_{50}$ & Fiducial limit & Equation & $x^{2}$ & RR & $P$ value $(\mathrm{df}=5)$ \\
\hline \multirow[t]{4}{*}{$\overline{L_{1}}$} & SS & $0.45 \pm 0.14$ & $0.12-1.00^{a}$ & $0.18+1.06$ & 6.68 & 1 & 0.25 \\
\hline & FSD & $1.03 \pm 0.41$ & $0.61-1.98^{\mathrm{ab}}$ & $0.16 X+0.56$ & 8.61 & 2.28 & 0.12 \\
\hline & MLT & $1.59 \pm 0.53$ & $0.84-2.87^{\mathrm{abc}}$ & $0.14 X+0.34$ & 9.70 & 3.53 & 0.08 \\
\hline & BWP & $2.83 \pm 0.75$ & $1.53-4.90^{\mathrm{bcd}}$ & $0.16 X-0.13$ & 12.74 & 6.25 & 0.02 \\
\hline \multirow[t]{4}{*}{$L_{2}$} & SS & $1.10 \pm 0.10$ & $0.60-2.77^{\mathrm{a}}$ & $0.16 X+0.86$ & 1.29 & 1 & 0.94 \\
\hline & FSD & $2.96 \pm 0.72$ & $1.73-4.73^{\mathrm{ab}}$ & $0.14 X+0.38$ & 5.11 & 2.68 & 0.40 \\
\hline & MLT & $4.43 \pm 1.08$ & $3.11-6.46^{b c}$ & $0.14 X+0.21$ & 4.72 & 4.01 & 0.45 \\
\hline & BWP & $5.91 \pm 1.40$ & $3.87-8.49^{\mathrm{bcd}}$ & $0.15 X-0.01$ & 4.60 & 5.35 & 0.46 \\
\hline \multirow[t]{4}{*}{$\mathrm{L}_{3}$} & SS & $2.01 \pm 0.95$ & $1.00-4.02^{\mathrm{a}}$ & $0.13+0.61$ & 1.21 & 1 & 0.94 \\
\hline & FSD & $4.65 \pm 1.02$ & $2.02-8.11^{\mathrm{ab}}$ & $0.14 X+0.39$ & 5.49 & 2.31 & 0.36 \\
\hline & MLT & $6.24 \pm 1.38$ & $2.72-9.48^{\mathrm{abc}}$ & $0.14 X+0.20$ & 9.57 & 3.09 & 0.09 \\
\hline & BWP & $7.85 \pm 3.28$ & $4.45-10.76^{\mathrm{bcd}}$ & $0.16 X-0.02$ & 8.78 & 3.89 & 0.12 \\
\hline
\end{tabular}

populations of S. frugiperda. Moreover, the effective concentration $\left(\mathrm{EC}_{50}\right)$ ranged from 48.65 to 163.60 and 21.76 to $70.09 \mathrm{ng}$ Vip3Aa20 $\mathrm{cm}^{-2}$ for D. saccharalis and S. frugiperda, respectively. Obtained results are in agreement with those of Hernandez-Martınez et al. (2008) who recorded toxic effects of different toxins from $B t$ on the $S$. exigua. Likewise, Moar et al. (1995) and Ashfaq et al. (2000) concluded that Cry1Ac was the most effective against lepidopterans and reported approximately 500 -fold resistance than the susceptible strain. The variability of $B t$ toxin in different cotton genotypes forced the farming community to shift towards continuous spraying of chemical insecticides in southern Pakistan. The repeated sprays resulted to develop other insect pests. The present study showed that good management of $S$. exigua under field conditions should be used only these varieties, which have higher $B t$ expression or dual toxin genotypes. Resistance in $S$. exigua to these types of Cry toxins can be overcome by planting new and better expression genotypes. The penetration of single Cry toxin varieties has been huge that might induce more serious risk and ultimately reflected in control failure.

\section{Conclusion}

The present study established a benchmark for the susceptibility of $S$. exigua to Bt Cry1Ac toxin. The results provided a background of developing a high-level resistance of transgenic Bt cotton varieties against Spodoptera spp. The data is important to policy-makers and technology providers; those develop strategies for the exploitation of transgenic Bt-cotton varieties as a component of IPM strategy.

Table 4 Molt inhibitory concentration of susceptible and field population of Spodoptera exigua to Cry1Ac toxin during 2016

\begin{tabular}{|c|c|c|c|c|c|c|c|}
\hline Larval instars & POP & $\mathrm{MIC}_{50}$ & Fiducial limit & Equation & $x^{2}$ & $\mathrm{RR}$ & $P$ value $(\mathrm{df}=5)$ \\
\hline \multirow[t]{4}{*}{$\overline{L_{1}}$} & SS & $0.05+0.00$ & $0.01-0.07^{\mathrm{a}}$ & $-0.21 X-2.23$ & 2.00 & 1 & 0.85 \\
\hline & FSD & $0.12+0.02$ & $0.08-0.51^{b}$ & $-0.12 X-1.38$ & 0.49 & 2.64 & 0.99 \\
\hline & $M L T$ & $0.40+0.06$ & $0.10-0.81^{b c}$ & $-0.17 X-1.19$ & 0.74 & 8.53 & 0.98 \\
\hline & BWP & $0.63+0.08$ & $0.11-1.73^{\mathrm{bcd}}$ & $-0.17 X-0.99$ & 0.49 & 13.43 & 0.93 \\
\hline \multirow[t]{4}{*}{$L_{2}$} & SS & $0.08+0.01$ & $0.04-0.21^{\mathrm{a}}$ & $-0.15 X-1.84$ & 0.04 & 1 & 1.00 \\
\hline & FSD & $0.32+0.06$ & $0.07-0.80^{\mathrm{ab}}$ & $-0.16 X-1.03$ & 0.64 & 4.10 & 0.99 \\
\hline & MLT & $0.70+0.09$ & $0.19-1.41^{b c}$ & $-0.15 X-0.83$ & 0.14 & 8.91 & 1.00 \\
\hline & BWP & $1.23+0.30$ & $0.66-2.75^{\mathrm{bcd}}$ & $-0.13 X-0.56$ & 0.26 & 15.63 & 0.99 \\
\hline \multirow[t]{4}{*}{$\mathrm{L}_{3}$} & SS & $0.11+0.07$ & $0.07-0.42^{\mathrm{a}}$ & $-0.14 X-1.49$ & 0.52 & 1 & 0.99 \\
\hline & FSD & $0.66+0.13$ & $0.22-1.17^{\mathrm{ab}}$ & $-0.16 X-0.89$ & 0.62 & 5.99 & 0.99 \\
\hline & MLT & $0.93+0.21$ & $0.35-1.69^{b c}$ & $-0.16 X-0.69$ & 0.94 & 8.39 & 0.97 \\
\hline & BWP & $1.71+0.54$ & $0.82-3.34^{\mathrm{bcd}}$ & $-0.15 X-0.41$ & 0.24 & 15.44 & 0.79 \\
\hline
\end{tabular}




\section{Abbreviations}

Bt: Bacillus thuringiensis; BWP: Bahawalpur; Cry: Crystalline; FSD: Faisalabad; GMP: Good management practices; IPM: Integrated pest management; L:D: Light and dark; $\mathrm{L}_{1}$ : First instar larva; $\mathrm{L}_{2}$ : Second instar larva; $\mathrm{L}_{3}$ : Third instar larva; LC: Lethal concentration; MIC: Molt inhibitory concentration; MLT: Multan; NaCl: Sodium chloride; NIAB: Nuclear Institute of Agriculture and Biotechnology; POP: Population; RH: Relative humidity; RR: Resistance ratio; SS: Susceptible; UK: United Kingdom

\section{Acknowledgements}

The authors are thankful to the Higher Education Commission of Pakistan for providing funding facilities to conduct research study.

\section{Authors' contributions}

All authors read and approved the final manuscript.

\section{Funding}

Higher Education Commission, Pakistan, provided funding for conducting research study.

\section{Availability of data and materials}

Data will not be shared

\section{Ethics approval and consent to participate}

Not applicable

\section{Consent for publication}

Not applicable

\section{Competing interests}

The authors declare that they have no competing interests.

\section{Author details}

${ }^{1}$ Department of Entomology, University of Agriculture Faisalabad, Faisalabad 38040, Pakistan. ${ }^{2}$ Department of Plant Pathology, University of Agriculture Faisalabad, Faisalabad, Pakistan.

Received: 18 May 2019 Accepted: 9 August 2019

Published online: 21 August 2019

\section{References}

Abbott WS (1925) A method of computing the effectiveness of an insecticide. J Econ Entomol 18:265-267

Arshad M, Suhail A (2011) Field and laboratory performance of transgenic Bt cotton containing CrylAc against beet armyworm larvae (Lepidoptera: Noctuidae). Pakistan J Zool 43:529-535

Ashfaq M, Young SY, Mcnew RW (2000) Development of Spodoptera exigua and Helicoverpa zea (Lepidoptera: Noctuidae) on transgenic cotton containing CrylAc insecticidal protein. J Entomol Sci 35:360-372

Bernardi O, Amado D, Sousa RS, Segatti F, Fatoretto J, Burd AD, Omoto C (2014) Baseline susceptibility and monitoring of Brazilian populations of Spodoptera frugiperda (Lepidoptera: Noctuidae) and Diatraea saccharalis (Lepidoptera: Crambidae) to Vip3Aa20 Insecticidal Protein. J Econ Entomol 107:781-790

Hamed M, Nadeem S (2008) Rearing of Helicoverpa armigera (Hub.) on artificial diets in laboratory. Pakistan J. Zool 40:447-450

Heckel DG (1993) Mapping Bt resistance genes in tobacco budworm: how many needles in the haystack? Presented at Pacific Entomol Conf Honolulu. pp. 15-25.

Hernandez-Martınez P, Ferre J, Escriche B (2008) Susceptibility of Spodoptera exigua to 9 toxins from Bacillus thuringiensis. J Invertebr Pathol 97:245-250

Hofs JL, Schoeman A, Vaissayre M (2004) Effect of Bt cotton on arthropod biodiversity in South African cotton fields. Comm Agric Appl Biol Sci 69:191-194

Kashyap S, Amla DV (2007) Characterization of Bacillus thuringiensis Kurstaki strains by toxicity, plasmid profiles and numerical analysis of their Cry1A genes. Afr J Biotechnol 6:1821-1827

LeOra Software (2003) Poloplus, A User's Guide to Probit and Logit Analysis. LeOra Software, Barkeley, CA

Lu YH, Wu KM, Jiang YY, Xia B, Li P (2010) Mirid bug outbreaks in multiple crops correlated with wide-scale adoption of Bt cotton in China. Sci 328:1151-1154

Moar WJ, Pusztai-Carey M, Frutos R, Rang C, Luo K, Faassen HV, Adang MJ, Bosch D (1995) Development of Bacillus thuringiensis Crylc resistance by Spodoptera exigua (Hübner) (Lepidoptera: Noctuidae). Appl Environ Microbiol 61:2086-2092
Osoria A, Martinez AM, Schneider MI, Diaz O, Corrales JL, Aviles MC, Smagghe G, Pineda S (2008) Monitoring of beet armyworm resistance to spinosad and methoxyfenozide in Mexico. Pest Manag Sci 64:1001-1007

Ponsard S, Gutierrez AP, Mills NJ (2002) Effect of Bt-toxin (Cry IAc) in transgenic cotton on the adult longevity of four heteropteran predators. Environ Entomol 31:1197-1205

Sayyed AH, Moores G, Crickmore N, Wright DJ (2008) Cross-resistance between a Bacillus thuringiensis Cry toxin and non-Bt insecticides in the diamondback moth. Pest Manage Sci 64:813-819

Selvi C, Krishnamoorty SV, Sivasubramanian P (2012) Bioefficacy of Bt cotton hybrids containing the fusion gene Cry1Ac- 1 Ab against Spodoptera litura. Indian J Plant Prot 40:22-25

Shorey HH, Hale RL (1965) Mass-rearing of the larvae of nine Noctuid species on a simple artificial medium. J Econ Entomol 58:522-524

Smith RH (1997) An extension entomologist's 1996 observations of Bollgard (Bt) technology. Proceeding Beltwide Cotton Conf New Orleans, LA, USA, 6-10 January 2: 856-858

Wei Y, Wu S, Yang Y, Wu Y (2017) Baseline susceptibility of field populations of Helicoverpa armigera to Bacillus thuringiensis Vip3Aa toxin and lack of crossresistance between Vip3Aa and Cry toxins. Toxins 9:127

Zhang JH, Guo JY, Xia JY, Wan FH (2012) Long-term effects of transgenic Bacillus thuringiensis cotton on the non-target Aphis gossypii (Homoptera: Aphididae) maintained for multiple generations. Afr J Biotechnol 11:9873-9880

\section{Publisher's Note}

Springer Nature remains neutral with regard to jurisdictional claims in published maps and institutional affiliations.

\section{Submit your manuscript to a SpringerOpen ${ }^{\circ}$ journal and benefit from:}

- Convenient online submission

- Rigorous peer review

- Open access: articles freely available online

High visibility within the field

- Retaining the copyright to your article

Submit your next manuscript at $\boldsymbol{\nabla}$ springeropen.com 